\title{
Effect of Gum Arabic (Acacia senegal) on C-reactive protein level among sickle cell anemia patients
}

\author{
Lamis AbdelGadir Kaddam ${ }^{1^{*}}$ (1) and Anas Suliman Kaddam²
}

\begin{abstract}
Objectives: Inflammation is ongoing process among sickle cell anemia even during steady state. $C$ reactive protein (CRP) is cardinal marker that utilized widely as inflammatory indicator. Gum Arabic (GA) is gummy exudates from Acacia senegal tree. Fermentation by colonic bacteria increases serum butyrate concentrations, so considered as prebiotic agent. Gum Arabic (GA) has anti-inflammatory activity through butyrate. Earlier we proved that regular intake of GA increased fetal hemoglobin and anti-oxidant capacity most likely through raised level of butyrate, which would ameliorate symptoms of sickle cell anemia. Best of our knowledge this is the first study conducted to investigate GA intake on inflammatory markers among sickle patients.

Results: This was a retrospective study conducted on stored samples from trial of Gum Arabic and sickle cell anemia. Quantitative CRP was measured by Mindray BS 200 before and after Gum Arabic consumption for 12 weeks. Daily intake of GA significantly decreased C reactive protein level $(P . V=001)(95 \% \mathrm{Cl} 0.943-3.098)$. No correlation between CRP and age, fetal hemoglobin, hemolysis markers and white blood cells. Our findings revealed novel effect of GA as anti-inflammatory agent could be consumed as natural dietary supplement to modulate disease severity and downregulate inflammatory process.
\end{abstract}

Trial registration: ClinicalTrials.gov Identifier: NCT02467257. Registered 3rd June 2015

Keywords: Gum Arabic, Sickle cell, Inflammation, CRP and butyrate

\section{Introduction}

Sickle cell Anemia (SCA) is an autosomal recessive genetic disease that results from solitary point mutation in position 6 of the $\beta$-globin chain, leading to production of hemoglobin $\mathrm{S}$ (HbS) [1]. Africa is the main origin of the sickle $(\beta S)$ mutations $[2,3]$. Polymerization of deoxygenated sickle hemoglobin is the primary event in the molecular pathogenesis of sickle cell disease and is responsible for the vasoocclusive phenomena which is the hallmark of the disease [4]. Sickle cell

\footnotetext{
*Correspondence: lamiskaddam@hotmail.com

1 Department of Physiology Faculty of Medicine, Alneelain University, P.O Box: 11121, 12702 Khartoum, Sudan

Full list of author information is available at the end of the article
}

disease (SCD) has long been recognized as an inflammatory condition and oxidative stress plays important role in pathophysiology of SCA [5]. SCA Patients have multiple indicators of an inflammatory response, including raised white cell counts, C-reactive protein (CRP) levels, cytokines, as well as activated monocytes, neutrophils, platelets, and endothelial cells [4]. Liver produced CRP as part of the acute phase reaction, in response to a host of pro inflammatory cytokines [6, 7]. CRP has wide acceptance as reliable indicator of systematic inflammation and tissue damage [7, 8]. Elevated levels of CRP, as a general marker of inflammation, have been previously reported in SCD patients and sickle mice $[5,9]$. Elevated CRP in SCA patients may be in response to endothelium damage due to 
vascular endothelium blockage by sickle erythrocytes [5]. Further, it seem like CRP is elevated even during free crisis time i.e. among steady state condition $[6,10]$. CRP elevation during steady state may be attributed to sub clinical vaso occlusive episodes, which raise covert inflammatory response [10]. This response is mediated by cytokines primarily IL6 [10].

The US FDA recognized Gum Arabic (GA) as one of the safest dietary fibres [11, 12].GA is indigestible for both human and animals; its fermentation by colonic intestinal bacteria leads to formation of various degradation products, such as short-chain fatty acids [13]. Gum Arabic ingestion increases serum short chain fatty acid concentration, mainly butyrate and propionate $[11,14]$. Serum butyrate concentration increased following administration of GA in healthy subjects $[11,15]$. Butyrate has a potent anti-inflammatory effect. It decreases the proinflammatory cytokine expression through inhibition of NFkB $[16,17]$. Oral intake of GA has been shown to provide several health benefits [18], such as prebiotic effects [12]. GA has immune-modulatory [13, 19], anti-inflammatory [20], and antioxidant properties [11, 12, 21, 22].

We hypothesized GA degradation delivers short chain fatty acids, which in turn have been shown to stimulate fetal hemoglobin expression in RBCs as studied previously [23]. Also, serves as anti-inflammatory agent through Short Chain Fatty Acids (SCFA) production and provide some protection against damaging effects of inflammation and vaso-occlusive crisis. The present study tested whether Gum Arabic may influence the CRP level.

To the best of our knowledge, this is the first study conducted to investigate the effect of oral administration of GA on inflammatory markers in sickle cell anemia patients.

\section{Main text \\ Methods}

This is retrospective study conducted on stored blood samples of GA and Sickle cell clinical trial. Entry criteria, clinical monitoring, and laboratory measurements have been described in detail previously [23]. Patients were in steady state as define as crisis- free period for 3 weeks and 3 months or more after last blood transfusion [10]. Blood samples were collected before administering GA and after 12 weeks, as stated in the trial protocol [22].

Two $\mathrm{ml}$ in EDTA container, Three $\mathrm{ml}$ in plain container. The serum and plasma was separated by centrifugation and stored at $-85^{\circ} \mathrm{C}$. Blood samples were stored between twelve and eighteen months prior to analysis. Studies revealed that CRP can remains stable more than ten years when kept at/less than $-80^{\circ} \mathrm{C}[24,25]$.

\section{Gum Arabic administration}

GA dose and administration were described in details in the previous report [23]. Properties and composition of GA are listed elsewhere [21].

Quantitative CRP was measured by Mindray BS 200 using turbidimetry method and expressed in $\mathrm{mg} / \mathrm{L}$. The principle of the test: Determination of the concentration of CRP through photometric measurement of immunocomplex between antibodies of CRP and CRP present in the sample, the absorbency increase is directly proportional to the concentration of CRP [26].

Data were analyzed using SPSS version 24. Paired samples $\mathrm{T}$ test was used to compare between pre and post intervention results. Person correlation was utilized to study correlation between contentious variables. P values equal or less than 0.05 was considered significant.

\section{Results}

Thirty-four samples were available for CRP analysis before and after GA administration. Patients' background characteristics are presented in Table 1. All were Sudanese; $50 \%$ were males (age 5 to 42 years). Five patients were on a stable dose of hydroxyurea 500 g per day. Duration of treatment was for 12 weeks.

Daily oral intake of GA significantly decreased CRP level (Fig. 1).

CRP showed no significant correlation with age, $\mathrm{HbF}$ level, TWBCs counts, Platelets count, and LDH level (Table 2).

\section{Discussion}

Sickle cell disease is the most common hemoglobin defect around the globe, with a high incidence in subSaharan Africa [27]. There is strong evidence generating a close connection between chronic inflammatory processes and sickle cell disease $[28,29]$. Which it seems as inherent characteristic of sickle endothelia cells [29]. Inflammation has fundamental role in many comorbidity and mortality associated with SCD like acute chest syndrome for example. CRP is the most commonly assessed marker for acute and chronic inflammation [28]. In the current study, we revealed no significant relation between CRP level and $\mathrm{Hb} F$ (Table 2). Our results are comparable to earlier study, who interpret their results to other external factors like inflammation and vaso-occlusion due to SCA [6]. Monocytes, neutrophils, and platelets are also actively involved in the various adhesive interactions and clinical manifestations [30]. Chronic hemolysis plays major role in inflammation, among steady-state HbSS patients likely through subclinical vascular endothelial injury and transient vasoocclusive events [9]. Conversely, none of hemolytic markers (LDH, Reticulocyte counts, 
Table 1 Demographics and baseline characteristics

\begin{tabular}{|c|c|c|c|c|c|}
\hline Characteristics & Mean & SD & Median & Minimum & Maximum \\
\hline Age & 15.65 & 8.9 & 14 & 5 & 42 \\
\hline Gender & 17(50\%) Male & & & & \\
\hline Base line weight (Kg) & $35 \cdot 34$ & 1.68 & 35 & 13 & 63 \\
\hline Base line height $(\mathrm{Cm})$ & $147 \cdot 1$ & $23 \cdot 21$ & $154 \cdot 5$ & 107 & 190 \\
\hline $\mathrm{Hb}(\mathrm{g} / \mathrm{dL})$ & 7.28 & 1.105 & 7 & 11 & 5.5 \\
\hline $\mathrm{Hb} F(\%)$ & 7.83 & 6.53 & 6.2 & .00 & 29.60 \\
\hline $\mathrm{Hb} \mathrm{S}(\%)$ & 88.89 & 6.22 & 91 & 68.00 & 97.00 \\
\hline CRP (mg/L) & 4.22 & 5.89 & 2.3 & 0.10 & 27.80 \\
\hline WBCs $\left(10^{3} / \mathrm{uL}\right)$ & 14.51 & 4.45 & 13.8 & 7.60 & 26.00 \\
\hline LDH (U/L) & 688.19 & 220.44 & 630 & 352.00 & 1250.00 \\
\hline
\end{tabular}

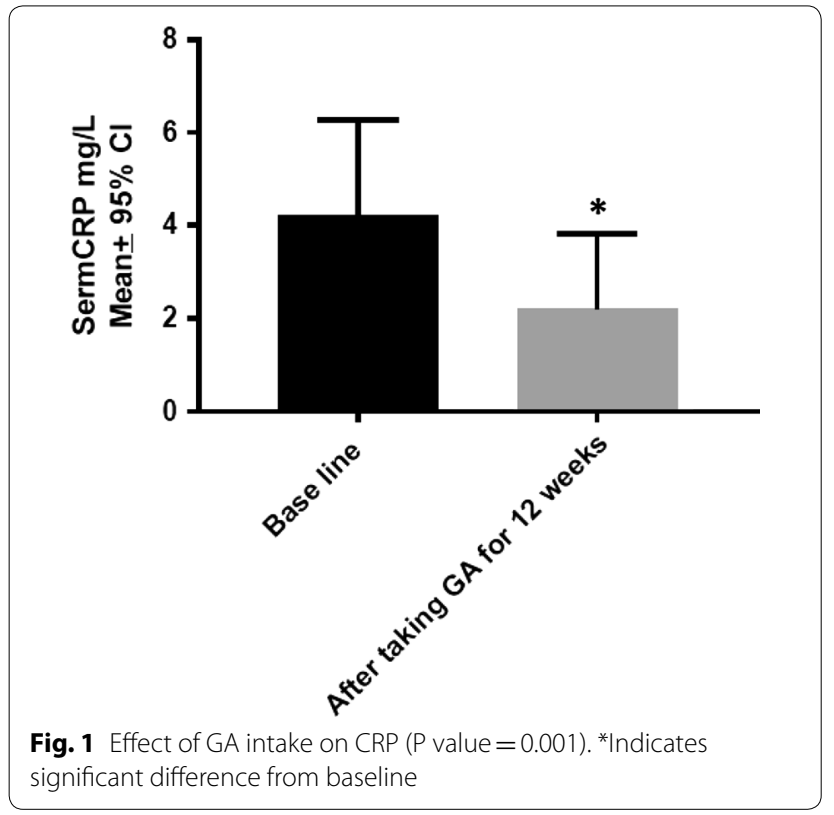

Table 2 Correlation of different biomarkers with CRP level among SCA patients

\begin{tabular}{lcc}
\hline Bio marker & Person correlation & P value \\
\hline Age & -.091 & 0.608 \\
Hb F & -.133 & 0.452 \\
Hemoglobin & .169 & 0.339 \\
WBCs & .155 & 0.383 \\
Platelets & -.124 & 0.486 \\
Reticulocytes & .146 & 0.589 \\
LDH & -.300 & 0.101 \\
Urea & -.180 & 0.333 \\
Creatinine & .070 & 0.710 \\
\hline
\end{tabular}

$\mathrm{Hb}$ concentration) correlated statistically with CRP level in this study (Table 2). CRP level could be activated by other pro-inflammatory cytokines such as Tumor Necrosis Factor $\alpha$ and IL-1b [9], which found consistently elevated among SCA patients [31]. These results were confirmed later by other investigators who found no significant difference between TNF $\alpha$ and other inflammatory cytokines level between SCA in steady state and in vaso-occlusive crisis [30].

GA significantly decreased CRP level (Fig. 1). This novel effect of GA may be of great importance, since inflammation is a cardinal component of the pathophysiology of SCD [32].

Earlier studies reveled GA anti-inflammatory effects as it decreased several inflammatory markers as TNF $\alpha$, ESR and CRP [19, 20]. Reduction of CRP level could be accredited to GA prebiotics properties. Since several studies proposed that alteration in gut microbiota can alleviate inflammation [33-35]. SCFAs in particular butyrate have strong anti-inflammatory effect $[16,17$, 36].

GA clinical trial among sickles induced $\mathrm{HbF}$ production [23] and this may have a role in reduction of ongoing inflammatory process and decreases CRP level. Nevertheless, we found no significant correlation between CRP and fetal hemoglobin (Table 2). On the other hand, there is strong relation concerning oxidative stress and inflammation and both are linked to SCD pathogenesis [5, 32, 37-39]. Earlier we documented GA exhibited strong anti-oxidant properties among SCA patients [22]. Therefore, reduction in CRP could be secondary to drop in oxidative stress markers. Numerous antioxidant therapies elicit anti-inflammatory responses [32].

In conclusion, our results reveled that inflammation among Sickle cell patients is ongoing process even during steady state period. GA significantly decreased 
CRP level, findings revealed an innovative effect of GA, which might be consumed as natural dietary fiber to attenuate inflammation in SCD patients and other pathogenesis linked with inflammatory process.

\section{Limitations}

The short trial duration precludes us to confirm the clinical significance of our results in modulation of disease severity and related mortality. The study is single arm with no control group. The inference of our findings, that GA displays anti-inflammatory action among SCA patients. Longer and multi arm studies are recommended to validate our findings.

\section{Abbreviations}

CRP: C reactive protein; GA: Gum Arabic; Hb: Hemoglobin; HbF: Fetal hemoglobin; IL6: Interleukin 6; LDH: Lactate dehydrogenase; SCD: Sickle cell disease; SCA: Sickle cell anemia.

\section{Acknowledgements}

We would like to thank Dar Savanna Ltd. Khartoum, Sudan (http://www.darsa vanna.net/) for providing Gum Arabic as gift for the study. We acknowledge Omer Ali Eisawi hematologist and Dr. Haydar Abdelrazig Pediatrician for their clinical contribution. We also thank department of clinical chemistry in Central laboratory Military hospital, for their valuable help in measuring hematological and chemical parameters.

\section{Authors' contributions}

LK and AK participated in study design. LK and AK were involved in all aspects of the study conduct. LK and AK analyzed data. AK performed laboratory studies. LK and AK participated in the writing and review of the manuscript. All authors read and approved final manuscript.

\section{Funding}

Supporting fund was obtained from Alneelain University Khartoum Sudan to principal Investigator LK. Funding bodies did not interfere in the design of the study and collection, analysis, and interpretation of data and in writing the manuscript.

\section{Availability of data and materials}

The datasets used and/or analyzed during the current study are included in the main text. Further data can be obtained from the corresponding author on reasonable request.

\section{Ethics approval and consent to participate}

The study was ethically approved from the Institutional Review Board at Alneelain University and from Research Ethics Committee- Sudan Academy of Sciences. Stored blood samples were coded, not identified by names. Data were kept anonymous. Informed consent is not applicable for this particular study.

\section{Consent for publication}

Not applicable.

\section{Competing interests}

No conflicts of interest, financial or otherwise, are declared by the authors.

\section{Author details}

${ }^{1}$ Department of Physiology Faculty of Medicine, Alneelain University, P.O. Box: 11121, 12702 Khartoum, Sudan. ${ }^{2}$ Department of Immunology, Institute of Tropical Medicine, Sudan Academy of Sciences, Khartoum, Sudan.
Received: 29 January 2020 Accepted: 11 March 2020

Published online: 18 March 2020

\section{References}

1. Fathallah $\mathrm{H}$, Atweh GF. Induction of fetal hemoglobin in the treatment of sickle cell disease. Hematol Am Soc Hematol Educ Program. 2006;9:58-62.

2. Diallo D, Tchernia G. Sickle cell disease in Africa. Curr Opin Hematol. 2002;9(2):111-6.

3. Makani J, Ofori-Acquah SF, Nnodu O, Wonkam A, Ohene-Frempong K. Sickle cell disease: new opportunities and challenges in Africa. Sci World J. 2013;2013:193252.

4. Belcher JD, Bryant CJ, Nguyen J, Bowlin PR, Kielbik MC, Bischof JC, et al. Transgenic sickle mice have vascular inflammation. Blood. 2003;101(10):3953-9.

5. Bhagat S, Patra PK, Thakur AS. Association of inflammatory bioker C-reactive protein, lipid peroxidation and antioxidant capacity marker with $\mathrm{HbF}$ level in sickle cell disease patients from Chattisgarh. Indian Clin Biochem. 2012;27(4):394-9.

6. Krishnan S, Setty Y, Betal SG, Vijender V, Rao K, Dampier C, et al. Increased levels of the inflammatory biomarker $C$-reactive protein at baseline are associated with childhood sickle cell vasocclusive crises. Br J Haematol. 2010;148(5):797-804

7. Pepys MB, Hirschfield GM. C-reactive protein: a critical update. J Clin Invest. 2003;111(12):1805-12.

8. Hirschfield GM, Pepys MB. C-reactive protein and cardiovascular disease: new insights from an old molecule. QJM. 2003;96(11):793-807.

9. Archer DR, Stiles JK, Newman GW, Quarshie A, Hsu LL, Sayavongsa P, et al. C-reactive protein and interleukin- 6 are decreased in transgenic sickle cell mice fed a high protein diet. J Nutr. 2008;138(6):1148-52.

10. Bourantas KL, Dalekos GN, Makis A, Chaidos A, Tsiara S, Mavridis A. Acute phase proteins and interleukins in steady state sickle cell disease. Eur J Haematol. 1998;61(1):49-54.

11. Ali BH, Ziada A, Blunden G. Biological effects of gum arabic: a review of some recent research. Food Chem Toxicol. 2009;47(1):1-8.

12. Babiker R, Merghani TH, Elmusharaf K, Badi RM, Lang F, Saeed AM. Effects of Gum Arabic ingestion on body mass index and body fat percentage in healthy adult females: two-arm randomized, placebo controlled, doubleblind trial. Nutr J. 2012;11:111.

13. Ballal A, Bobbala D, Qadri SM, Foller M, Kempe D, Nasir O, et al. Antimalarial effect of gum Arabic. Malar J. 2011;10:139.

14. Tulung B, Remesy C, Demigne C. Specific effect of guar gum or gum arabic on adaptation of cecal digestion to high fiber diets in the rat. J Nutr. 1987;117(9):1556-61.

15. Matsumoto N, Riley S, Fraser D, Al-Assaf S, Ishimura E, Wolever T, et al. Butyrate modulates TGF-beta1 generation and function: potential renal benefit for Acacia(sen) SUPERGUM (gum arabic)? Kidney Int. 2006;69(2):257-65.

16. Luhrs H, Gerke T, Muller JG, Melcher R, Schauber J, Boxberge F, et al. Butyrate inhibits NF-kappaB activation in lamina propria macrophages of patients with ulcerative colitis. Scand J Gastroenterol. 2002;37(4):458-66.

17. Luhrs H, Gerke T, Schauber J, Dusel G, Melcher R, Scheppach W, et al. Cytokine-activated degradation of inhibitory kappaB protein alpha is inhibited by the short-chain fatty acid butyrate. Int J Colorectal Dis. 2001;16(4):195-201.

18. Nasir O. Renal and extrarenal effects of gum arabic (Acacia senegal)what can be learned from animal experiments? Kidney Blood Press Res. 2013;37(4-5):269-79.

19. Ali BH, Al-Husseni I, Beegam S, Al-Shukaili A, Nemmar A, Schierling S, et al. Effect of gum arabic on oxidative stress and inflammation in adenineinduced chronic renal failure in rats. PLOS ONE. 2013;8(2):e55242.

20. Kamal E, Kaddam LA, Dahawi M, Osman M, Salih MA, Alagib A, et al. Gum arabic fibers decreased inflammatory markers and disease severity score among rheumatoid arthritis patients, Phase II Trial. Int J Rheumatol. 2018;2018:4197537

21. Nasir O, Umbach AT, Rexhepaj R, Ackermann TF, Bhandaru M, Ebrahim A, et al. Effects of gum arabic (Acacia senegal) on renal function in diabetic mice. Kidney Blood Press Res. 2012;35(5):365-72. 
22. Kaddam L, Fadl-Elmula I, Eisawi OA, Abdelrazig HA, Salih MA, Lang F, et al. Gum Arabic as novel anti-oxidant agent in sickle cell anemia, phase II trial. BMC Hematol. 2017;17:4.

23. Kaddam L, FdleAlmula I, Eisawi OA, Abdelrazig HA, Elnimeiri M, Lang F, et al. Gum Arabic as fetal hemoglobin inducing agent in sickle cell anemia; in vivo study. BMC Hematol. 2015;15:19.

24. Doumatey AP, Zhou J, Adeyemo A, Rotimi C. High sensitivity C-reactive protein (Hs-CRP) remains highly stable in long-term archived human serum. Clin Biochem. 2014:47(4-5):315-8.

25. Aziz N, Fahey JL, Detels R, Butch AW. Analytical performance of a highly sensitive C-reactive protein-based immunoassay and the effects of laboratory variables on levels of protein in blood. Clin Diagn Lab Immunol. 2003;10(4):652-7.

26. Tugirimana PL, Holderbeke AL, Kint JA, Delanghe JR. A new turbidimetric method for assaying serum C-reactive protein based on phosphocholine interaction. Clin Chem Lab Med. 2009:47(11):1417-22.

27. Diallo DA, Guindo A. Sickle cell disease in sub-Saharan Africa: stakes and strategies for control of the disease. Curr Opin Hematol. 2014;21(3):210-4

28. Damanhouri GA, Jarullah J, Marouf S, Hindawi SI, Mushtaq G, Kamal MA. Clinical biomarkers in sickle cell disease. Saudi J Biol Sci. 2015;22(1):24-31.

29. Sakamoto TM, Lanaro C, Ozelo MC, Garrido VT, Olalla-Saad ST, Conran $\mathrm{N}$, et al. Increased adhesive and inflammatory properties in blood outgrowth endothelial cells from sickle cell anemia patients. Microvasc Res. 2013;90:173-9.

30. Pathare A, Al KS, Alnaqdy AA, Daar S, Knox-Macaulay H, Dennison D. Cytokine profile of sickle cell disease in Oman. Am J Hematol. 2004;77(4):323-8.

31. Francis RB Jr, Haywood LJ. Elevated immunoreactive tumor necrosis factor and interleukin-1 in sickle cell disease. J Natl Med Assoc. 1992;84(7):611-5.
32. Owusu-Ansah A, Ihunnah CA, Walker AL, Ofori-Acquah SF. Inflammatory targets of therapy in sickle cell disease. Transl Res. 2016;167(1):281-97.

33. Cani PD, Possemiers S, Van de Wiele T, Guiot Y, Everard A, Rottier O, et al. Changes in gut microbiota control inflammation in obese mice through a mechanism involving GLP-2-driven improvement of gut permeability. Gut. 2009;58(8):1091-103.

34. Kang Y, Cai Y, Zhang X, Kong X, Su J. Altered gut microbiota in RA: implications for treatment. Z Rheumatol. 2017;76(5):451-7.

35. Khanna S, Jaiswal KS, Gupta B. Managing rheumatoid arthritis with dietary interventions. Front Nutr. 2017;4:52.

36. Cavaglieri CR, Nishiyama A, Fernandes LC, Curi R, Miles EA, Calder PC. Differential effects of short-chain fatty acids on proliferation and production of pro- and anti-inflammatory cytokines by cultured lymphocytes. Life Sci. 2003;73(13):1683-90.

37. Jison ML, Munson PJ, Barb JJ, Suffredini AF, Talwar S, Logun C, et al. Blood mononuclear cell gene expression profiles characterize the oxidant, hemolytic, and inflammatory stress of sickle cell disease. Blood. 2004;104(1):270-80.

38. Emokpae MA, Uadia PO, Gadzama AA. Correlation of oxidative stress and inflammatory markers with the severity of sickle cell nephropathy. Ann Afr Med. 2010;9(3):141-6.

39. Biswal S, Rizwan H, Pal S, Sabnam S, Parida P, Pal A. Oxidative stress, antioxidant capacity, biomolecule damage, and inflammation symptoms of sickle cell disease in children. Hematology. 2018;16:1-9.

\section{Publisher's Note}

Springer Nature remains neutral with regard to jurisdictional claims in published maps and institutional affiliations.
Ready to submit your research? Choose BMC and benefit from:

- fast, convenient online submission

- thorough peer review by experienced researchers in your field

- rapid publication on acceptance

- support for research data, including large and complex data types

- gold Open Access which fosters wider collaboration and increased citations

- maximum visibility for your research: over $100 \mathrm{M}$ website views per year

At BMC, research is always in progress.

Learn more biomedcentral.com/submissions 